\title{
Satellite archives reveal abrupt changes in behavior of Helheim Glacier, southeast Greenland
}

\author{
VICTORIA V. MILES, ${ }^{1,2}$ MARTIN W. MILES, ${ }^{3,2,4}$ OLA M. JOHANNESSEN ${ }^{1,5}$ \\ ${ }^{1}$ Nansen Environmental and Remote Sensing Center, Bergen, Norway \\ ${ }^{2}$ Bjerknes Centre for Climate Research, Bergen, Norway \\ ${ }^{3}$ Uni Research Climate, Bergen, Norway \\ ${ }^{4}$ Institute of Arctic and Alpine Research, University of Colorado, Boulder, CO, USA \\ ${ }^{5}$ Nansen Scientific Society, Bergen, Norway \\ Correspondence: Victoria V. Miles<victoria.miles@nersc.no>
}

\begin{abstract}
Rapid changes in Helheim Glacier and other Greenland outlet glaciers since 2000 are wellknown, but knowledge on earlier decades is fragmentary. Here we exploit the satellite image archives to produce and analyze a monthly-to-seasonal record of Helheim Glacier front position, 1980-2011. Statistical analysis identifies decadal periods with abrupt changes in variability and mean. The record also reveals evidence of volatile advance/retreat behavior in the 1980s. In one of several cases of large-amplitude subannual changes, the glacier front 'surged' forward in 1984/85, advancing $\sim 6 \mathrm{~km}$ within a few months - surpassing its Little Ice Age maximum position - and afterward retreated $\sim 5 \mathrm{~km}$ within a few weeks. These findings challenge the prevailing view of front position stability in the decades before the multi-year retreat in the early 2000s. Cold conditions including rigid ice mélange appear to be a factor in the high-amplitude seasonal advances in the 1980s. However the magnitude and abruptness of the changes in the record cannot be explained solely as a climatic response, such that glacio-dynamics must be invoked. Further, the volatile advance/retreat behavior in the cold 1980s resulted in increased dynamic ice loss, complicating the interpretation of increased calving activity as a response to warming.
\end{abstract}

KEYWORDS: Arctic glaciology, Greenland, glacier fluctuations, calving

\section{INTRODUCTION}

Ice discharge from marine-terminating outlet glaciers accounts for approximately half the recent mass losses from the Greenland Ice Sheet (van den Broeke and others, 2009). Rapid changes in ice velocity and discharge from marine-terminating glaciers in the 2000s have been widely reported (Rignot and Kangnaratham, 2006), particularly in southeast Greenland, apparently in response to oceanic and/or atmospheric warming (Howat and others, 2007, 2008; Murray and others, 2010; Seale and others, 2011). The dynamical behavior of marine-terminating glaciers, including Helheim Glacier, has also been the subject of numerical modeling studies (Nick and others, 2009, 2013), stressing the importance of changes at the terminus or calving front. The recent variability of Helheim Glacier ice velocity and calving front position has been studied in detail using satellite remote sensing (e.g. Rignot and others, 2004; Howat and others, 2005, 2007, 2008; Stearns and Hamilton, 2007; Joughin and others, 2008; Schild and Hamilton, 2013). However, knowledge on its variability before the 2000s is fragmentary, as there are few long-term observational records with high temporal resolution.

Multidecadal satellite studies of Helheim and other outlet glaciers have provided valuable long-term perspective, as have century-scale sediment-based proxy records of Helheim Glacier calving activity (Andresen and others, 2012; Andersen and others, 2014). However, long-term satellite studies typically have low temporal resolution and/or discontinuous, fragmentary sampling. Howat and Eddy (2011) studied glaciers around Greenland including Helheim from the early 1970 s to 2010 . They found that the magnitude and extent of retreat increased in the early 1990s, coincident with the onset of warming following several decades of cooling and glacier stability. Their results suggest that the retreat over the decade 2000-2010 is the most extensive of the four decades surveyed; however, that study did not resolve sub-decadal variability but used decadal aggregation based on a few individual years. Mernild and others (2012) covered the period $1972-2011$, but used only 5 years dispersed over the period. Bjørk and others (2012) spanned several decades using archival aerial photographs and satellite images, but again with several years between observations. Luckman and others (2006) studied Helheim Glacier surface velocity and front position back to 1992, finding that the velocity remained steady during the 1990s despite progressive and substantial thinning of $\sim 2 \mathrm{~m} \mathrm{a}^{-1}$ near the terminus (Abdalati and others, 2001).

There have been two studies of Helheim Glacier that have covered at least two decades at high temporal resolution. Johannessen and others (2011) produced an annual (end of summer) record of calving front position from 1981 to 2010, and found interannual variability to be more strongly correlated with air temperature than ocean temperature; however, subannual variability (e.g. seasonal advance/ retreat) was not resolved. Bevan and others (2012) produced a subannual to annual record from 1985 to 2011, improving on the records by Luckman and others (2006) and Johannessen and others (2011), although the temporal sampling in some years (1985/86 and 1993-95) has gaps such that the seasonal fluctuations are missing. 
The prevailing view from previous studies is that, on the one hand, Helheim is a dynamic glacier that can change rapidly, as evidenced by a $6^{+} \mathrm{km}$ multi-year retreat, 2001-05 (Howat and others, 2005). On the other hand, the glacier is widely assumed to have been stable in the preceding decades, for example: (a) 'several decades of apparent stability' (Howat and others, 2008), (b) the front 'appears to have been relatively stable from 1985 to 2001, varying only 1-2 km' (Johannessen and others, 2011) and (c) 'prior to retreat and acceleration, Helheim is shown to be stable for at least 16 years' with only 'some evidence of interannual variability' (Bevan and others, 2012).

Except from the singular retreat then re-advance in the early 2000s, no rapid changes of comparable magnitude have actually been observed before or since. A fundamental question is whether this apparent stability is real or rather due to sampling limitations of previous studies of Helheim Glacier. It is important to expand the observational datasets in order to ascertain the full range of natural variability.

Here we exploit the satellite archives to produce and analyze a high temporal resolution (monthly-seasonal) record of Helheim Glacier front position, 1980-2011. The new aspects are: (1) unprecedented length for a high-resolution record, which extends the published record (Bevan and others, 2012) with improved temporal sampling, thereby resolving seasonal to interdecadal variability; (2) identification of decadal and sub-decadal periods marked by abrupt changes in mean and variability of the front position; (3) identification of previously-unreported volatile advance/retreat behavior in the 1980s and (4) identification of decadal differences in calving activity resulting from different dynamical behavior.

\section{DATA AND METHODS}

\subsection{Study area}

Helheim Glacier $\left(66.4^{\circ} \mathrm{N}, 38^{\circ} \mathrm{W}\right)$ is one of the largest Greenland outlet glaciers in terms of ice-sheet drainage basin area and ice discharge (Fig. 1). Based on ice discharge, Helheim has been ranked as the third (e.g. Rignot and others, 2004) or fifth largest (Enderlin and others, 2014), depending on the study period, underscoring the importance of temporal sampling. Helheim is also one of the fastest flowing; depending on the study and period sampled, its typical speed ranges from 5 to $6 \mathrm{~km} \mathrm{a}^{-1}\left(\sim 15 \mathrm{~m} \mathrm{~d}^{-1}\right)$ from 1986 to 1995 (Luckman and others, 2006; Bevan and others, 2012), and between 7 and $11 \mathrm{~km} \mathrm{a}^{-1}\left(21-30 \mathrm{~m} \mathrm{~d}^{-1}\right)$ during the 2000s (Bevan and others, 2012). The glacier flows through a large steep-walled fjord with complicated bed topography (Schjøth and others, 2012; Bamber and others, 2013; Morlighem and others, 2014) that has an influence on the calving front, which is 5-6 km wide and $\sim 900 \mathrm{~m}$ thick near its terminus position (Joughin and others, 2008). It is the largest of the three tidewater glaciers that terminate into Sermilik Fjord, the largest fjord system in southeast Greenland. Sermilik Fjord has a connection to temperate Atlantic waters from branches of the Irminger Current that can reach the southeast Greenland shelf, flow beneath the cold ice-laden East Greenland Current (EGC) and East Greenland Coastal Current (EGCC) and penetrate and circulate at depth in the fjord. Although temperate waters reaching the southeast Greenland shelf is not only a recent occurrence, there are indications of a marked increase that began in the mid to late 1990s (Johannessen and others, 2011; Andresen and others, 2012; Straneo and Heimbach, 2013). The temperature of subsurface waters (200-600 m depth) within the fjord is on the order of $4{ }^{\circ} \mathrm{C}$, compared with $-1{ }^{\circ} \mathrm{C}$ for the surface waters (Straneo and others, 2010; Johannessen and others, 2011).

\subsection{Satellite data and geographic information system (GIS) integration}

We compiled an extensive amount of satellite data, including unexploited archival satellite images from the 1980s, in order to produce a longer high-temporal-resolution data record than in previous studies. The temporal coverage is densest during spring/summer/autumn (from March to October), while synthetic aperture radar (SAR) data cover the winter months as well. During the period from March to October for each year, we have at least one image mon ${ }^{-1}$, usually more than one.

Altogether we acquired nearly 1000 images from several sensor systems. The number of images from each sensor system analyzed here is summarized in Table 1. Most Landsat 5 and 7 thematic mapper (TM) and Landsat-7 Enhanced Thematic Mapper Plus (ETM+) data over Greenland are ortho-rectified using known satellite positioning, sensor orientation, ground control and a DEM. Landsat 1-5 multispectral scanner are processed to a level in which geometric corrections are applied using only satellite positioning, which we improved with a tie-point co-registration. The scan-line correction (SLC) system on the ETM+ failed in May 2003, however, these data are of the same radiometric and geometric quality as the SLC-on data. To mitigate the impact of the data stripes on our analysis, we used a de-striping algorithm for Landsat7 SL/off (http://landsat.usgs.gov/ ERDAS_Approach.php). SPOT (Satellite Earth Observation System) has relatively good coverage for southeast Greenland especially in the 1990s. Even 'quick-look' SPOT images have proven to be effective for detecting glacier front position (Johannessen and others, 2011) and were added to the database. The European Remote Sensing 1/2 SAR data, which have $\sim 25 \mathrm{~m}$ resolution, are available from the European Space Agency since July 1991. The SAR images were used primarily for the winter season.

The disparate satellite images were imported and consistently co-registered in the geographic information system ArcGIS for analysis. All types of data were co-registered and re-projected to Universal Transverse Mercator projection. Co-registration to overlapping Landsat $\mathrm{ETM}^{+}$data acquired in 2000 was done using visible, stationary tie points (e.g. rock outcrops, bends in coastline) near the glacier margin. For each image, we selected at least ten points, adding more tie points until the RMS of the differences in tie-point locations between the images did not increase with the addition of more tie points. This process resulted in the selection of 10-25 tie points. The images were then warp-registered to the tie-point locations using an affine transformation and bilinear re-sampling (Campbell, 2002).

\subsection{Glacier front position}

For each image integrated in the GIS, we manually mapped the ice front position, and measured the distance from the edge to a reference point for each ice front position. 




Fig. 1. Location of Helheim Glacier $\left(66.4^{\circ} \mathrm{N}, 38^{\circ} \mathrm{W}\right)$ and other outlet glaciers that terminate in Sermilik Fjord, southeast Greenland. The blue circle indicates the nearest meteorological station Tasiilaq. The orange circles indicate the sediment cores (Andresen and others, 2012; Andersen and others, 2014).

Because of the extensive number of images, we measured the front position using for the simple 'central line' approach instead of the 'box' method, as sensitivity tests have found that the two methods yield similar results, within $\pm 100 \mathrm{~m}$ (e.g. Walsh and others, 2012). The centerline method is far less labor intensive and measurements can be made when the front is partially obscured. Therefore, by using this method we increased the temporal sampling of glacier front position.

Errors in front position can arise from sensor resolution, geo-location error as well as error in the precision of manual digitizing. Image data prior to 1999 have lower resolution and thus comprise the upper limit of errors. Front

Table 1. Summary of the satellite imagery used in the study

\begin{tabular}{llc}
\hline Satellite sensor & \multicolumn{1}{c}{ Time period } & $\begin{array}{c}\text { Number of } \\
\text { images }\end{array}$ \\
\hline Landsat4 TM & 1980-92; 1995 & 180 \\
SPOT 1-5 & 1985-96, 1999-2002, & 76 \\
& 2005,2006 & \\
ERS1/SAR & $1992-99$ & 60 \\
ERS2/SAR & $2006-08$ & 9 \\
Landsat 7 ETM+ & $1999-2011$ & 100 \\
\hline
\end{tabular}

positions were all digitized by a single operator to avoid any inter-operator bias. Relative errors (arising from all sources) were estimated by measuring the distance between two features for randomly selected images $(\sim 30)$ from different sensors, the standard deviation for vector length was calculated. The estimated error is $\sim \pm 60 \mathrm{~m}(1-2$ pixels), which is more than an order of magnitude less than the Helheim Glacier front variability.

\subsection{Glacier calving activity}

Estimates of calving amounts for each year were made by identifying cumulative area change from the time series of ice-front positions. This was done using a translational motion method by subtracting the distance from the reference point to glacier front position from the distance to the previous position and then multiplying by the glacier width at the position. Because measuring the actual area calved would require regular sampling throughout, as well as knowledge on ice-flow at each time step - conditions not met here - this is only a semi-quantitative indicator of calving amounts. While this definition involves an element of subjectivity, we argue that it provides a useful relative indicator of year-to-year calving activity, which we further compare with calving proxies (Andresen and others, 2012; 2014). 


\subsection{Glacier velocity}

Although there are radar interferometric ice velocity datasets for Greenland glaciers including Helheim, their temporal coverage is inadequate for this study. The multidecadal time series of Helheim surface flow speed produced by Bevan and others (2012) for the late 1980s through the 2000s provides a useful baseline. Here, glacier surface velocity was extracted from imagery in selected periods of interest in the mid-1980s with large-amplitude changes in the front position. Several techniques have been developed to measure ice flow velocity (Bindschadler and Scambos, 1991; Csatho and others, 1999; Howat and others, 2007). Visual (manual) feature tracking from consecutive images has been demonstrated to provide results comparable with automated methods (Whillans and Tseng, 1995). Here, we determined velocity by tracing features in Landsat image pairs between 10 and $30 \mathrm{~d}$ apart. The flow speed velocity was measured near the calving front. At least 12 points (e.g. crevasses that could be identified on both images) were selected. Then the distance between the same features in the two images was tracked manually, and a digital vector overlay was produced.

\subsection{Statistical methods}

Statistical methods were applied to the time series of front position and derived parameters, in order to provide metrics and to identify and test for changes. Time series characteristics of interest are mean, variability and trend. Here the term 'trend' denotes a multiyear change in front position $>2 \mathrm{~km}$; i.e. not a long-term secular trend.

Statistical techniques were applied to objectively delimit different periods that may be subjectively apparent in the time series. A simple approach adapted from change-point analysis theory (e.g. Chen and Gupta, 2000) was used to locate the exact location of change-points, which are instances in time where the statistical properties before and after this time point differ. Here we tested different windows to optimally delimit the periods, based on maximizing $W$, the Levene's test statistic for homogeneity in variance (Levene, 1960) in adjacent periods.

Within each major period (1980-91, 1991-2001 and 2001-11), statistics for central tendency (mean) and variability (range, variance and rate-of-change (based on leastsquares fit)) of the front position were calculated and where appropriate, tested for statistical significance (at $\alpha=0.05$ ). The magnitude of the seasonal cycle of advance and retreat was calculated with each period as the best-fit sinusoidal curve, as in harmonic analysis; this is a conservative measure of amplitude compared with a maximum-tominimum ('peak to trough') measurement, which would require more complete sampling.

\subsection{Climate and ocean data}

The possible response of Helheim Glacier to climate forcing was explored through comparing the 30 a of glacier front position with time series of nearby meteorological measurements (temperature and precipitation), as well as indicators of sea ice/ocean conditions.

Surface air temperature (SAT) and precipitation measurements are available from the Danish Meteorological Institute coastal station at Tasiilaq (WMO ID 04360), which is $80-90 \mathrm{~km}$ southeast of the Helheim ice front. This is the closest station to Helheim Glacier that has a multidecadal record of measurements; although there are nearby AWS, none have any measurements before the 1990s. The Tasiilaq data analyzed are monthly, here aggregated into different seasons and an annual average.

Ocean temperature measurements taken within Sermilik Fjord are lacking except for a few years of field campaigns in the 2000s (e.g. Straneo and others, 2010; Johannessen and others, 2011). Therefore, proxy indicators of local ocean conditions are needed. Here we considered three different proxies: (1) a paleo proxy reconstruction of temperature within Sermilik Fjord based on alkenone in sediment cores (Andresen and others, 2013), which are however not annually resolved, (2) annual time series from Irminger Sea hydrographic measurements $\sim 400 \mathrm{~m}$ depth that have been used as a proxy for subsurface fjord water advected under the EGC and EGCC (Johannessen and others, 2011) and (3) annual time series of a 'shelf index' indicative of polar water and sea ice versus Atlantic water on the southeast Greenland shelf, developed by Andresen and others (2012). The shelf index is based on combining standardized measurements of ocean temperature south of Iceland together with observations of polar-origin sea ice ('Storis') along the Greenland coast (Schmith and Hansen, 2003). Of these three proxies for ocean conditions near Helheim Glacier, the shelf index is emphasized here, as it is an integrated indicator of ocean/ice conditions, and has been related to Helheim Glacier calving (Andresen and others, 2012).

Sea ice and ice mélange (a mixture of sea ice and icebergs sikkusak in Greenlandic) conditions near the Helheim Glacier front were characterized for each year based on visible-band images available from late winter (March typically, and February-March from the 1990s onward). This temporal sampling - albeit incomplete - was necessary to feasibly produce a consistent classification for each year, 1980 to 2011. The characterization follows the classification from Moon and others (2015): rigid, mixed (potentially rigid) and open (unlikely rigid). In addition, the same method was performed using several images from 1984-86, to focus on the extreme advance/retreat event 1984/85.

\section{RESULTS}

\subsection{High-resolution multidecadal time series}

The new high-temporal resolution record of Helheim Glacier front positions 1980-2011 is shown in Figure 2. Differences between the two curves in the figure demonstrate the advantages of subannual sampling compared with the annual (end of summer) sampling that was presented by Johannessen and others (2011). The $30^{+}$year high-resolution time series $(N=218)$ is amenable to statistical analysis to constrain its variability ranging from seasonal to interdecadal time scales, and to place the 2000s changes in a longer-term perspective.

In the multidecadal perspective, the front position in August 2005 - at the end of the multi-year retreat 200105 ( $R_{1}$ in Fig. 2) - is confirmed to be unprecedented in the satellite record, $4.5 \mathrm{~km}$ farther back than the most retracted position observed earlier in the time series, in September 1980. For several years before and after the retreat and readvance 2001-06 ( $R_{1}$ and $A_{1}$ in Fig. 2$)$, the front positions are generally stable, with a stationary mean and low variability 


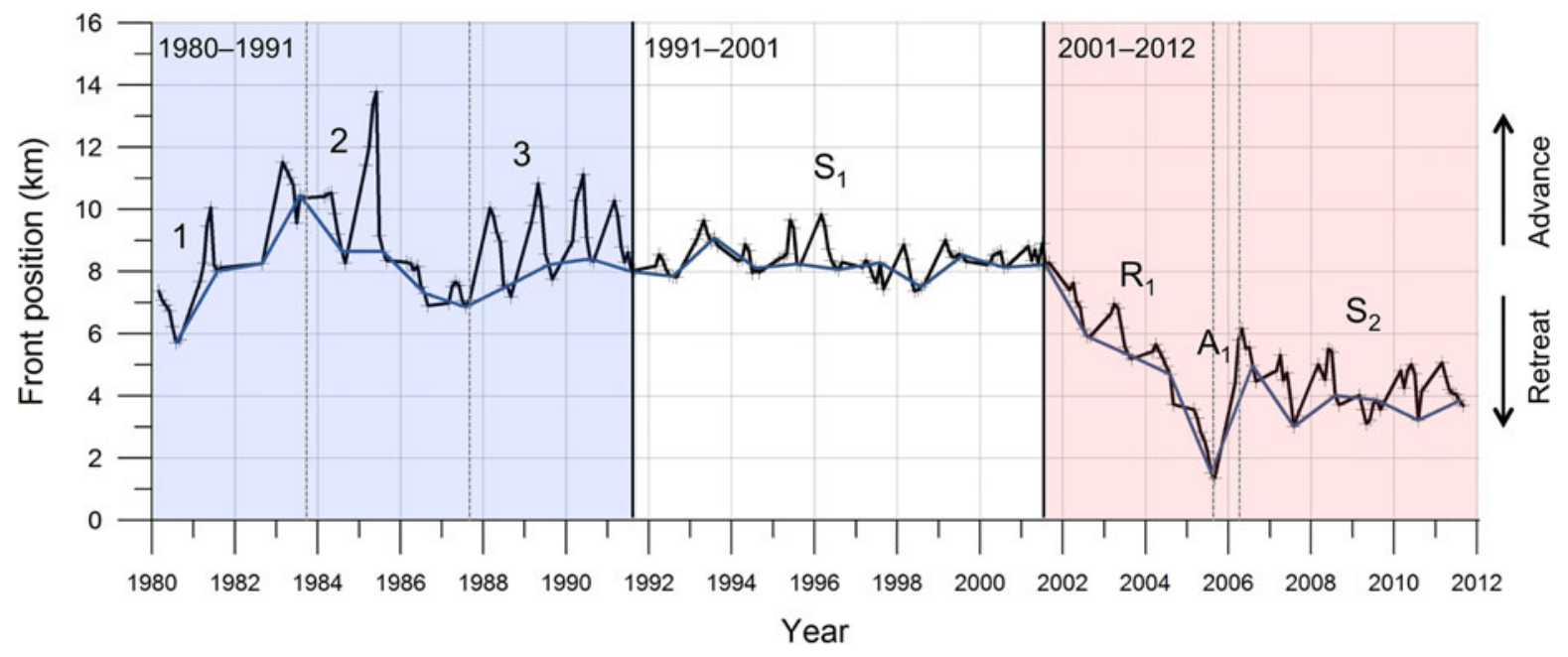

Fig. 2. Helheim Glacier front position 1980-2011. Blue curve: annual (end-of-summer) values, updated from Johannessen and others (2011). Black curve: subannual values from this paper. Shading indicates three decadal periods of different variability: 1980-91, 1991-2001, and 2001-11; the dashed gray lines delimit sub-periods. Stable periods/sub-periods with stationary means are labeled $S_{1}$ and $S_{2}$. Largeamplitude variations are labeled: (1) multiyear advance, 1980-83; (2) 'surge-like' advance 1984/85 and retreat 1985/86; (3) enhanced seasonal advance/retreat oscillation, 1987-91; $\left(R_{1}\right)$ multiyear retreat, 2001-05; and $\left(A_{1}\right)$ re-advance, 2005-06. Front positions are relative to an arbitrary reference point (plotted in Fig. 5).

$\left(|\Delta \mathrm{x} / \Delta \mathrm{t}|<2 \mathrm{~km} \mathrm{a}^{-1}\right)$. The two periods of stability are denoted $S_{1}(1990-2001)$ and $S_{2}(2006-12)$ in Figure 2. These periods $S_{1}$ and $S_{2}$ are in agreement with the prevailing view of Helheim Glacier front stability, aside from the 2001-06 retreat and readvance (Howat and others, 2008; Johannessen and others, 2011; Bevan and others, 2012).

However, the time series also reveals evidence of previously unseen behavior in the 1980s. There were several rapid and large-amplitude changes $\left(|\Delta \mathrm{x} / \Delta \mathrm{t}|>2 \mathrm{~km} \mathrm{a}^{-1}\right)$ in calving front positions (labeled 1, 2 and 3 in Fig. 2), the largest being a $6 \mathrm{~km}$ advance within a few months in 1984/ 85 , followed by a $5 \mathrm{~km}$ retreat within a few weeks. The furthermost front position $\left(x_{\max }\right)$ in June 1985 extended 12.5 $\mathrm{km}$ beyond its most retreated position $\left(x_{\min }\right)$ in August 2005, such that the observed range of the Helheim Glacier front position is $\sim 50 \%$ greater than the $8 \mathrm{~km}$ suggested from previous studies (e.g. Andresen and others, 2012, Supplementary material).

\subsection{Decadal and sub-decadal changes}

Markedly abrupt changes in variability are apparent in the $30^{+}$year record of calving front position (Fig. 2). Based on their statistical properties, the time series can be divided into three approximately decadal periods: 1980-91, 19912001 and 2001-12 (shading in Fig. 2), with change points located at August 1991 and July 2001. These decadal periods are hereafter referred to as the 1980s, 1990s, and 2000s respectively. Sub-decadal periods with different characteristics are further identified within the 1980s and 2000s, while there were no significant changes within the 1990s.

The 1980s had markedly greater variability than in the 1990s or 2000s. The range of front positions was $8.1 \mathrm{~km}$, with a minimum observed in August 1980 and maximum in June 1985 . The 1980 s had a positive change in front position, with a $+0.15 \mathrm{~km} \mathrm{a}^{-1}$ linear rate of change from 1980 to 1991. This was the net result of: (1) a sub-period of advance (1980-83) (2) a sub-period of retreat (1984-87) and (3) a subperiod of advance (1987-91), labeled 1, 2 and 3 in Figure 2. More notable than these multiyear 'trends' is the superposed volatile variability on seasonal to interannual time scales. In contrast to the 1990s and 2000s, the 1980s are characterized by multiple episodes of rapid advance and retreat $>2 \mathrm{~km}$. Between September 1980 and June 1981 the glacier front advanced $4.3 \mathrm{~km}$, and again advanced $3.3 \mathrm{~km}$ between September 1982 and March 1983. During this sub-period 1980-83 (' 1 ' in Fig. 2), the general advance was $5.5 \mathrm{~km}$, which is the largest multiyear 'trend' in the record. During the subsequent sub-period 1984-86 (' 2 ' in Fig. 2), an even more pronounced advance-retreat episode occurred in $1984 / 85$, as described in the next sub-section. The 1980s also had a seasonal cycle that was much more pronounced than in subsequent decades: the mean amplitude 1980-91 was $\sim 2.2 \mathrm{~km}$, and during four consecutive years (1987-91; ' 3 ' in Fig. 2) the seasonal oscillation was even larger ( 2.8 $\mathrm{km}$ ) and nearly regular in amplitude.

The 1990s were a relatively quiescent period for Helheim Glacier front position. The period is characterized by front position stability, with low variability around a stationary mean $\left(S_{1}\right.$ in Fig. 2). The range of front positions was just $1.6 \mathrm{~km}$. There was no net change in front position; the linear rate of change 1991-2001 was insignificant at -0.03 $\mathrm{km} \mathrm{a}^{-1}$, and no observed retreats or advances $\geq 2 \mathrm{~km}$. While similar to the stable sub-period 2006-11 $\left(S_{2}\right.$ in Fig. 2) in having a stationary mean, there are two differences: (1) mean front position $\bar{x}$ during $S_{1}$ measured from the reference point is $8.4 \mathrm{~km}$, which is $5.1 \mathrm{~km}$ offset from the mean during $S_{2}$, and (2) variability $\sigma_{\mathrm{x}}$ during $S_{1}$ was significantly less than in $S_{2}$, based on the $W$ test-statistic for differences in variance (Levene, 1960). On subannual time scales, the seasonal oscillation in the 1990s was relatively small (amplitude $\sim 500 \mathrm{~m}$ ) and irregular.

The 2000s were characterized by a substantial net retreat. The linear rate of change from 2001-11 was $\sim-0.2 \mathrm{~km} \mathrm{a}^{-1}$; however this was clearly non-linear and primarily the result of the $6.6 \mathrm{~km}$ retreat from August 2001 to $2005\left(R_{1}\right.$ in Fig. 2). The subsequent re-advance between September 2005 and June $2006\left(A_{1}\right.$ in Fig. 2) has been followed by several years of moderate fluctuations $\left(|\Delta x / \Delta t|<2 \mathrm{~km} \mathrm{a}^{-1}\right)$ around a stable stationary mean $\left(S_{2}\right.$ in Fig. 2). Accordingly, 
the 2000s can be divided into three sub-periods $R_{1}, A_{1}$ and $S_{2}$, with change points in August 2005 and May 2006 (Fig. 2). On subannual timescales, there was an irregular seasonal fluctuation with an overall amplitude $\sim 1.3 \mathrm{~km}$.

\section{3. 'Surge-like' advance $\mathbf{1 9 8 4 / 8 5}$}

The most pronounced advance-retreat episode in the record occurred in 1984/85 (' 2 ' in Fig. 2). After a 2 km seasonal retreat in summer 1984, the glacier front appeared to have moved forward by nearly $6 \mathrm{~km}$ between two images from October 1984 and June 1985 (Figs 3a, d). Although there are no images available in the wintertime from October 1984 through February 1985, we subsequently found several images between 1 March and 26 May 1985 (Figs $3 \mathrm{~b}, \mathrm{c})$ that confirmed this advance to be real, rather than image displacement or interpretation error.

The sustained rate of frontal advance, as observed from several images between early March and 11 June 1985, was on the order of $30 \mathrm{~m} \mathrm{~d}^{-1}$ - reaching $1.1 \mathrm{~km} \mathrm{mon}^{-1}$. During the advance, feature-tracked measurements of surface ice velocities between 30 March and 11 June 1985 showed a speed-up from 18 to $\sim 30 \mathrm{~m} \mathrm{~d}^{-1}$ near the front (Fig. 4), and a speed-up from 14 to $18 \mathrm{~m} \mathrm{~d}^{-1}$ as measured $10-14 \mathrm{~km}$ from the glacier front. These flow speeds are $2 \times$ the background flow speed for Helheim from the late 1980s to the early 2000s, and are comparable with the maximum speeds during the acceleration near the end of the multiyear retreat in 2005 (Bevan and others, 2012). The front reached its most forward observed position as an ephemeral floating tongue (image date 11 June 1985; Fig. 3d), which exceeded the Little Ice Age (LIA) position (Khan and others, 2014). Afterwards the front retreated $4.9 \mathrm{~km}$ within a few weeks (image date 13 July 1985; Fig. 3e) during a massive calving episode. The tabular icebergs evident in Figure $3 e$ indicate that the glacier reached flotation. The frontal retreat continued nearly unabated until October 1986, a total retreat of $6.9 \mathrm{~km}$ from the June 1985 position.

Such an advance/retreat episode of several kilometers within a few months has never been previously observed for Helheim Glacier, and the retreat is of similar magnitude to 2001-05. For comparison, the front positions during the retreat in 2001-05 are plotted in Figure 5. Although of comparable magnitude and starting locations in 1984 and 2001 (Fig. 5), there are clear contrasts between the 1984 and 1985 and 2001-06 events:

(1) The advance in 1984/85 occurred before the retreat, whereas in the 2001-06 case, the advance occurred after the retreat; the 2005/06 re-advance has been explained as a dynamical adjustment to the removal of resistive stresses due to the loss of grounded ice (Howat and others, 2008; Joughin and others, 2008), whereas this is not the case for the advance in 1984/85.

(2) Glacier flow speed increased during the 1984/85 advance and then decreased during the subsequent retreat. This is in contrast to the inverse relationship between ice speed and front position observed for Helheim - for example, acceleration during the 2001-05 retreat and deceleration during the 2005/06 advance - and for other major Greenland tidewater glaciers in general (Bevan and others, 2012).

(3) The retreat in the early 2000 s - taken together with the near-synchronous acceleration and retreat elsewhere in
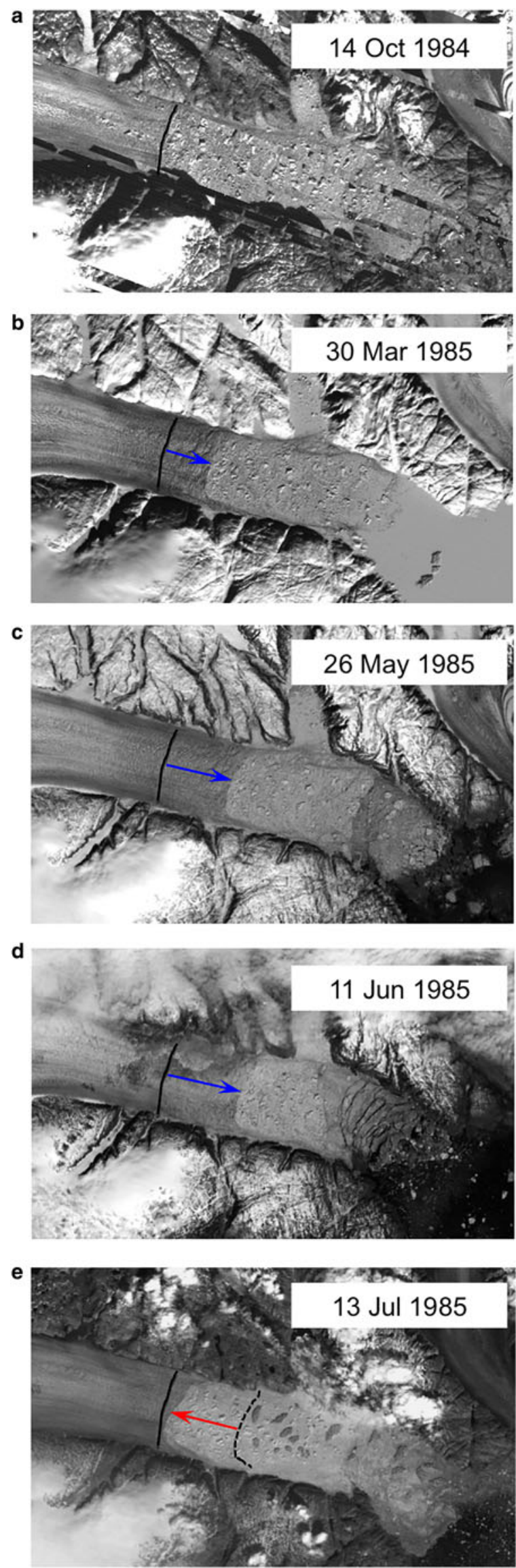

Fig. 3. Rapid advance and retreat of Helheim Glacier, 1984/85. Landsat image sequence: (a) 14 October 1984; (b) 30 March 1985; (c) 26 May 1985; (d) 11 June 1985; (e) 13 July 1985. The blue arrows in $(b-d)$ show the advance from the front position in October 1984 (black curve). The red arrow in (e) shows the retreat from the farthest advance (dashed curve) in (d). 


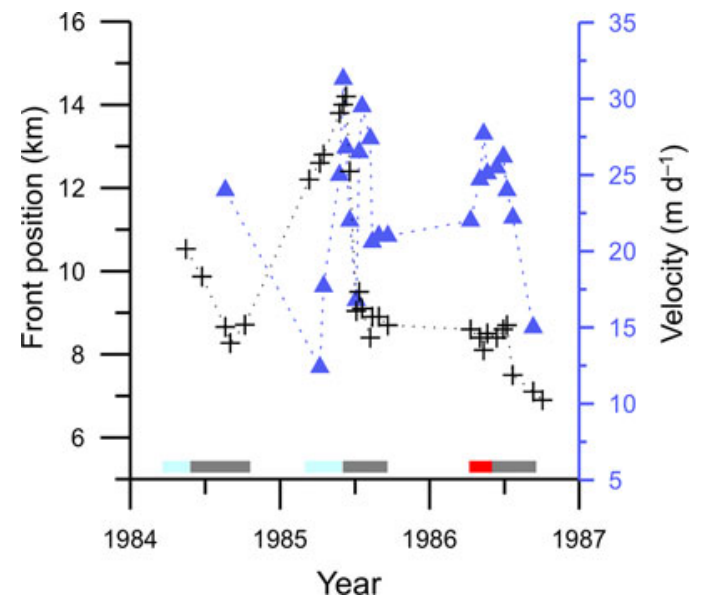

Fig. 4. Helheim Glacier front position (crosses), ice velocity (triangles) and ice mélange conditions (light blue = rigid, grey $=$ mixed, and red=open) during the advance/retreat 1984/85 through 1986.

southeast Greenland - was probably a response to oceanic and/or atmospheric warming (Howat and others, 2008; Murray and others, 2010; Johannessen and others, 2011; Seale and others, 2011). The rapid $6 \mathrm{~km}$ advance in 1984/85 cannot be readily explained as a temperature response.

\section{DISCUSSION}

\subsection{Glacio-climatic response or glacio-dynamics?}

The volatile glacier-front variability in the 1980s - highlighted by the $6 \mathrm{~km}$ advance during 1984/85 and several other largemagnitude advance/retreat episodes - was not expected given the known behavior from the 1990s to 2000s, decades that were characterized by relatively low variability around stable mean front positions $\left(S_{1}\right.$ and $S_{2}$ in Fig. 2), aside from the retreat then re-advance episode (2001-06).

The question is the degree to which the observed variability in the 1980s represents a glacio-climatic response to atmosphere/ocean variations (e.g. Howat and others, 2008; Joughin and others, 2008; Johannessen and others, 2011) and/or unstable glacier dynamics. Figure 6 shows a comparison between Helheim Glacier front position (1980-2011) and SAT, ocean sea ice conditions ('shelf index') and ice mélange conditions near the glacier front.

On the one hand, the magnitude of the subannual advance/retreat episodes in the 1980s, as well as the abruptness of changes in behavior through the record, is more pronounced than would be expected from the moderate temperature fluctuations. Further, although there was an amelioration of atmospheric and oceanic conditions throughout the 1990s, there was no large response of glacier front position, which remained stable until the rapid retreat began in 2001, coinciding with the abrupt onset of higher temperatures and higher shelf index (Figs 6a, b). The mean front position $\bar{x}$ during the 1990 s stable period $S_{1}$ may represent a 'preferred' position due to underlying factors associated with glacier basal topography and the grounding line. The same reasons may also explain the stability observed since 2006 (' $S_{2}$ ' in Figs 2, 5). The position of a glacier front relative to basal topography (e.g. a sill) influences the response of terminus position for a given forcing (Nick and others, 2009). Here comparison of the mean front position $\bar{x}$ during $S_{1}$ and $S_{2}$ with the basal topography based on the three data sources (Joughin and others, 2008; Bamber and others, 2013; Morlighem and others, 2014) suggests that $S_{1}$ coincides with a basal high, while $S_{2}$ may coincide with the inland margin of the sill, which the 3-D bed topography from Bamber and others (2013) and Morlighem and others (2014) indicates is shallower (in the

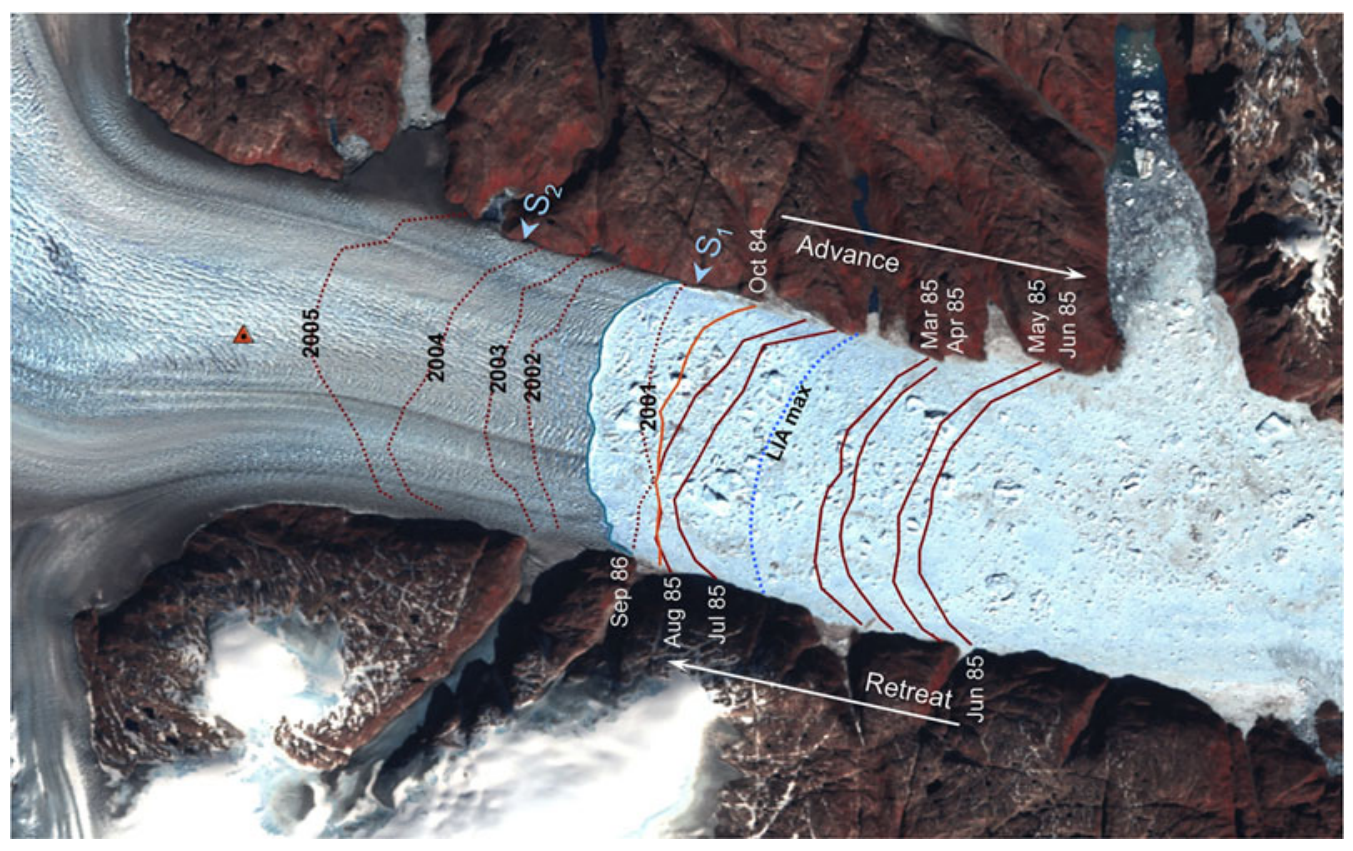

Fig. 5. Comparison of the rapid advance/retreat 1984/85 with the multi-year retreat in the early 2000s. Landsat image from September 1986 , overlain with two sets of curves. The solid red curves show positions during the advance in 1984/85 and retreat in 1985/86, labeled in white text. The dotted red curves show the yearly position for Helheim during the retreat in the early 2000s, labeled in black text. The blue dotted curve is the Little Ice Age (LIA) maximum (Khan and others, 2014). The blue arrows indicate the mean position during the stable periods $1991-2001\left(S_{1}\right)$ and 2006 onwards $\left(S_{2}\right)$, as in Figure 2. For reference, the red triangle is the 0-point for the front position measurements plotted in Figure 2. 


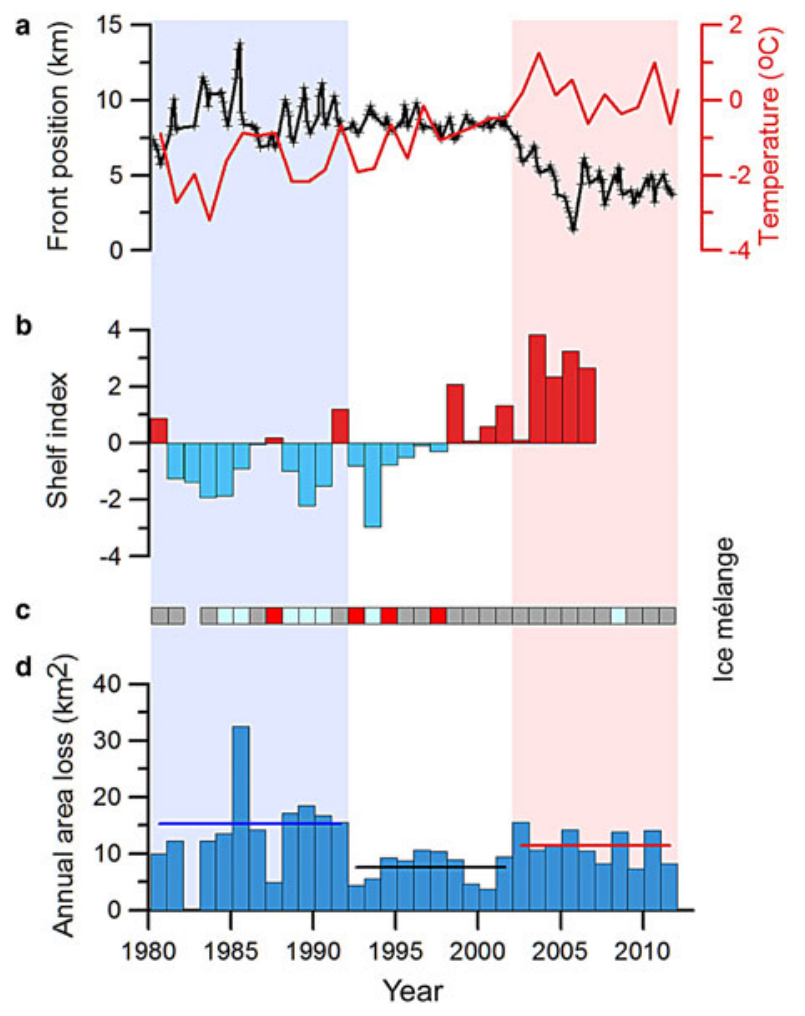

Fig. 6. Helheim Glacier calving front and comparison with climate data, 1980-2011: (a) Calving front position (black) and annual surface air temperature record (red) from the nearest station, Tasiilaq; (b) shelf index, an indicator of the relative amount of polar water and sea ice on the southeast Greenland shelf (from Andresen and others, 2012); (c) Ice mélange conditions in winter (light blue $=$ rigid, grey $=$ mixed and red $=$ open), and (d) Annual area loss, an indicator of calving activity; horizontal bars are the mean annual calving losses in each decadal period. 1982 - no observations.

southern part) than in the profile from Joughin and others (2008). The influence of basal topography on Helheim Glacier front stability is thus strongly suggested, in agreement with Joughin and others (2008) and Nick and others (2009).

On the other hand, some correspondence between the glacier front position and fluctuations of air temperature and ocean/sea ice conditions is apparent on interannual to decadal time scales, consistent with the interpretation of Johannessen and others (2011) and Andresen and others (2012). The 1980s were the coldest decade in terms of SAT and the ocean/ice shelf index (Figs 6a, b), and this was a period of general advance, with several advances $>2 \mathrm{~km}$ $\mathrm{a}^{-1}$. The individual seasonal advance/retreat episodes in the 1980s may also be connected, to some degree, with fluctuations in atmospheric and oceanic conditions. The advances from 1980 to 1983 (' 1 ' in Fig. 2), and three of the large-amplitude seasonal advances 1987-91 (' 3 ' in Fig. 2) appear to coincide with low temperatures (Fig. 6a), conditions that have been shown to be indirectly linked to stability or advances (e.g. Kjær and others, 2012). Moon and others (2015) found a strong correspondence between seasonal near-terminus sea ice/mélange conditions and terminus change for glaciers in northwest Greenland, with rigid ice mélange conditions associated with advance, and open water associated with retreat. Here we find that the four largest-amplitude seasonal advances (1984/85, 1987/88, 1988/89 and 1989/90) are associated with rigid ice mélange in winter, as suggested by Moon and others (2015).

However, not all of the seasonal advance/retreat episodes can be explained by ice mélange conditions and temperature fluctuations. For example, although winter 1990/91 was not cold and had mixed mélange, there was another $2 \mathrm{~km}$ seasonal advance, which was possibly a glacio-dynamical response to successive cold winters. Moreover, the largest advance in $1984 / 85$ (' 2 ' in Fig. 2) appears to be different from the aforementioned advance/retreat episodes, as supported by the acceleration that occurred, which is not typical for a mélange-based advance. The extreme magnitude $(6 \mathrm{~km})$ of the advance and the abrupt increase in velocity suggest unstable glacier dynamics. Although the generally fast-flowing Helheim Glacier cannot be considered a true surge-type glacier, it is notable that the observed rapid advance had the diagnostic characteristics of surging tidewater glaciers in their active phase: (1) increased glacier flow speeds, (2) frontal advance, (3) increased calving and (4) morphological changes such as increased crevassing and a surge bulge (Paterson, 1994; Jiskoot, 2011). It is also plausible that the advance in 1984/85 may have been facilitated by a mechanism hypothesized for glacial surging: meteorological conditioning leading to storage of large amounts of englacial water, which can gradually move downward subglacially and provide basal lubrication (e.g. Jiskoot, 2011). Enhanced precipitation in late summer of the previous year may trigger a surge the following spring (Jiskoot and Juhlin, 2009 and references therein). Here, the summer (JJA) rainfall amount in 1984 was the highest in the study period $->2 \times$ higher $(365 \mathrm{~mm})$ than normal (162 mm, Danish Meteorological Institute, http://www.dmi.dk) and the precipitation amounts were consistently high each month $(113 \mathrm{~mm}$ in June; $132 \mathrm{~mm}$ in July; $120 \mathrm{~mm}$ in August). It is possible that these conditions were conducive to the 'surge-like' advance.

\subsection{Enhanced calving activity in the coldest decade: $1980 \mathrm{~s}$}

The pronounced advance/retreat behavior in the 1980s implies enhanced calving activity during that decade, despite no overall retreat such as was seen in the 2000s. Here, based on cumulative area losses from observed calving-front retreats, we made indicative estimates of calving amounts each year 1980-2011 (except for 1982 because of missing data) and aggregated the results by period (Fig. 6c). The calving activity based on these estimates is highest during the period 1980-91, with high values each year (except for 1986, when the seasonal advance/retreat was absent following the 1984/85 episode). For example, the four consecutive years (1987-91) with a large-amplitude seasonal fluctuation appear to have even greater calving activity than during the several kilometer 2001-05 retreat, even though there was no net retreat during the 1987-91 subperiod. The lack of large-amplitude variability or trends in the period 1991-2001 resulted in approximately half of the calving-area losses compared with the 1980s. The 2000s had calving amounts intermediate between the 1980 and 1990s amounts; it is notable that the calving amounts in the 2000s were not only during the multi-year retreat 2001-05, but widely distributed throughout the decade as a result of repetitive advance/retreat fluctuations around a stationary mean from 2006 to 2011. 
These calving-area estimates are comparable with independent calving proxy records for Helheim based on marine sediment cores from Sermilik Fjord (Andresen and others, 2012; Andresen and others, 2014) - for reference, these are plotted in Figure 1. There is general correspondence between our satellite-derived estimates vis-à-vis the sediment-based calving proxy from Andresen and others (2012); their most proximal core ER13 shows peaks in the 1980s and early 2000s, and lower values in the 1990 s. Moreover, the Andresen and others (2014) cores 24 and 25 - located closer to the glacier - are a substantially better match to our estimates than the Andresen and others (2012); indeed their K/Ti-based calving reconstructions (their Figs $4 \mathrm{a}$ and b) closely match our estimates - with the 1980s appearing highest in both records.

These observations indicate that the dynamic behavior of Helheim Glacier can result in greater calving amounts during a cold period (with net advance) than during warm periods (with net retreat) such as the early 2000s. This confounds the interpretation of increased calving activity in proxy records as an indicator of retreat during warm phases (Andresen and others, 2012). Peaks in calving activity can also represent dynamic mass losses through enhanced advance/retreat behavior during a cold period with reduced air and ocean temperatures, as demonstrated here and elsewhere in Greenland during the 1980s (e.g. Kjær and others, 2012). Moreover, our calving estimates do not include changes in ice thickness. It is reasonable to infer that the mass losses through calving in the 1980s vis-à-vis the 2000s were even greater than inferred from the area estimates, assuming greater ice thickness in the 1980s (Khan and others, 2014, and suggested from trim lines in the imagery).

\section{CONCLUSIONS}

We exploited the satellite archives to develop a new longterm high-resolution record of calving front position for Helheim Glacier, 1980-2011. Analysis of this record has revealed new aspects that nuance the previous understanding of its variability:

(1) The front position has undergone abrupt changes in variability and mean, with major change points in 1991, 2001, 2005 and 2006, and secondary change points within the 1980s denoting sub-decadal changes.

(2) Two periods of stability, 1991-2001 and 2006 onward, are characterized by stationary mean and low variability $\left(<2 \mathrm{~km} \mathrm{a}^{-1}\right)$, although the mean front position $\bar{x}$ from 2006 onward is $5.1 \mathrm{~km}$ farther back than $\bar{x}$ from 1991 to 2001 . These positions may represent 'preferred' positions for the glacier, due to grounding and bed topography.

(3) There was volatile front position behavior in the 1980s, with several large-amplitude advance/retreat episodes on subannual to interannual time scales, including a $6 \mathrm{~km}$ 'surge-like' advance in 1984/85 - behavior that has not been recorded in previous studies of Helheim Glacier.

(4) There is some correspondence between the front position behavior and ice mélange associated with fluctuations of temperature and ocean conditions; however the magnitude of at least the 1984/85 advance appears greater, and changes in variability more abrupt than would be expected as a glacio-climatic response; thus glaciodynamics are important.

(5) Dynamic advance/retreat behavior during the cold 1980s with reduced air and ocean temperatures resulted in calving amounts that were greater in the 1980s than in the warm 2000s. This confounds the interpretation of increased ice discharge as a straightforward response to climate warming.

These findings underscore the complexity of marineterminating Greenland outlet glacier variability (Post and others, 2012) and point to the need for further exploration of the satellite and aerial photo archives (e.g. Bjørk and others, 2012; Kjær and others, 2012) to develop and analyze similar long-term, high-temporal-resolution records of other major Greenland outlet glaciers, in order to constrain and understand their natural variability. For example, a similar analysis of Fenris and Midgård glaciers, which also terminate in Sermilik Fjord, would allow testing the response of three proximal glaciers to essentially similar atmospheric and oceanic forcing, as well as improved interpretation of calving proxy records from marine sediment cores obtained in the fjord.

\section{ACKNOWLEDGEMENTS}

The lead author (V. V. Miles) acknowledges funding from the Trond Mohn Donation. We also acknowledge funding from the Centre for Climate Dynamics at the Bjerknes Centre through the SEALEV and MARGINS projects (M. W. Miles and V. V. Miles) and the Research Council of Norway through the EASTGREEN project (M. W. Miles). We thank the two anonymous reviewers whose suggestions greatly improved the manuscript. The satellite data were provided by the US Geological Survey and the European Space Agency. We thank K. Khvorostovsky, A. Korosov and M. Babiker (NERSC) for discussions and C. S. Andresen (GEUS) for data.

\section{REFERENCES}

Abdalati W and 9 others (2001) Outlet glacier and margin elevation changes: near-coastal thinning of the Greenland ice sheet. J. Ceophys. Res., 106, 33,729-33,741 (doi: 10.1029/2001JD900192) Andresen CS and 6 others (2012) Rapid response of Helheim Glacier in Greenland to climate variability over the past century. Nature Geosci., 5, 37-41 (doi: 10.1038/NGEO1349)

Andresen CS and 7 others (2013) A 100-year long record of alkenone-derived SST changes by Southeast Greenland. Continental Shelf Res., 71, 45-51 (doi: 10.1016/j.csr.2013.10.003)

Andresen CS and 10 others (2014) A 100-year record of changes in water renewal rate in Sermilik fjord and its influence on calving of Helheim Glacier, southeast Greenland. Continental Shelf Res., 85, 21-29 (doi: 10.1016/j.csr.2014.05.017)

Bamber JL and 10 others (2013) A new bed elevation dataset for Greenland. Cryosphere, 7, 499-510 (doi: 10.5194/tc-7-4992013)

Bevan SL, Luckman AJ and Murray T (2012) Glacier dynamics over the last quarter of a century at Helheim, Kangerdlugssuaq and 14 other major Greenland outlet glaciers. Cryosphere, 6, 923-937 (doi: 10.5194/tc-6-923-2012)

Bindschadler R and Scambos TA (1991) Satellite-image-derived velocity field of an Antarctic ice stream. Science, 252, 242-246 (doi: 10.1126/science.252.5003.242)

Bjørk AA and 6 others (2012) An aerial view of 80 years of climaterelated glacier fluctuations in southeast Greenland. Nature Geosci., 5, 427-432 (doi: 10.1038/NGEO1481) 
Campbell JB (2002) Introduction to remote sensing. 3rd Edn. Taylor and Francis, New York

Chen J and Gupta AK (2000) Parametric statistical change point analysis. Birkhauser, Boston

Csatho BM, Bolzan JF, van der Veen CJ, Schenk AF and Lee DC (1999) Surface velocities of a Greenland outlet glacier from high-resolution visible satellite imagery. Polar Geog., 23, 71-82 (doi: 10.1080/10889379909377665)

Enderlin EM and 5 others (2014) An improved mass budget for the Greenland Ice Sheet. Geophys. Res. Lett., 41, 866-872 (doi: 10.1002/2013GL059010)

Howat IM and Eddy A (2011) Multi-decadal retreat of Greenland's marine-terminating glaciers. J. Glaciol., 57, 389-396 (doi: 10.3189/002214311796905631)

Howat IM, Joughin I, Tulaczyk S and Gogineni S (2005) Rapid retreat and acceleration of Helheim Glacier, east Greenland. Geophys. Res. Lett., 33, L22502 (doi: 10.1029/2005GL024737)

Howat IM, Joughin I and Scambos TA (2007) Rapid changes in ice discharge from Greenland outlet glaciers. Science, 315, 15591561 (doi: 10.1126/science.1138478)

Howat IM, Joughin I, Fahnestock M, Smith BE and Scambos TA (2008) Synchronous retreat and acceleration of southeast Greenland outlet glaciers 2000-06: ice dynamics and coupling to climate. J. Glaciol., 54, 646-660

Jiskoot H (2011) Glacier surging. In Singh VP, Singh P, Pratap U., Haritashya eds. Encyclopedia of snow, ice and glaciers. Springer, Dordrecht, 1253 p., ISBN 10.1007/978-90-481-26422_559

Jiskoot H and Juhlin D (2009) Surge of a small East Greenland glacier, 2001-2007, suggests Svalbard-type surge mechanism. J. Glaciol., 55, 567-570 (doi: 0.3189/002214309788816605)

Johannessen OM, Korablev A, Miles V, Miles MW and Solberg KE (2011) Interaction between the warm subsurface Atlantic water in the Sermilik Fjord and Helheim glacier in southeast Greenland. Surv. Geophys., 32, 387-396 (doi: 10.1007/ s10712-011-9130)

Joughin I and 8 others (2008) Ice-front variation and tidewater behavior on Helheim and Kangerdlugssuaq Glaciers, Greenland. J. Geophys. Res., 113, F01004 (doi: 10.1029/ 2007 JF000837)

Khan SA and 11 others (2014) Glacier dynamics at Helheim and Kangerdlugssuaq glaciers, southeast Greenland, since the Little Ice Age. Cryosphere, 8, 1497-1507 (doi: 10.5194/tc-8-1497-2014)

Kjær KH and 13 others (2012) Aerial photographs reveal late-20thcentury dynamic ice loss in Northwestern Greenland. Science, 337, 569-573 (doi: 10.1126/science.1220614)

Levene H (1960) Robust tests for equality of variances. In Olkin I and others eds. Contributions to probability and statistics. Stanford University Press, Stanford, 278-292

Luckman A, Murray T, de Lange R and Hanna E (2006) Rapid and synchronous ice-dynamic changes in East Greenland. Geophys. Res. Lett., 33, L03503 (doi: 10.1029/2005GL025428)

Mernild SH, Malmros JK, Yde JC and Knudsen NT (2012) Multidecadal marine and land-terminating glacier recession. Cryosphere, 6, 625-639 (doi: 10.5194/tc-6-625-2012)

Moon T, Joughin I and Smith B (2015) Seasonal to multi-year variability of glacier surface velocity, terminus position, and sea ice/ice mélange in northwest Greenland. J. Geophys. Res., 120, 818-833 (doi: 10.1002/2015JF003494)
Morlighem M, Rignot E, Mouginot J, Seroussi H and Larour E (2014) Deeply incised submarine glacial valleys beneath the Greenland ice sheet. Nature Geosci., 7, 418-422 (doi: 10.1038/NGEO2167)

Murray T and 10 others (2010) Ocean regulation hypothesis for glacier dynamics in southeast Greenland and implications for ice sheet mass changes. J. Geophys. Res., 115, F03026 (doi: 10.1029/2009JF001522)

Nick F, Vieli A, Howat IM and Joughin I (2009) Large-scale changes in Greenland outlet glacier dynamics triggered at the terminus. Nature Geosci, 2, 110-114 (doi: 10.1038/ngeo394)

Nick F and 7 others (2013) Future sea-level rise from Greenland's main outlet glaciers in a warming climate. Nature, 497, 235238 (doi: 10.1038/nature12068)

Paterson WSB (1994) The physics of glaciers. 3rd edn., Elsevier, Oxford

Post A, O'Neel S, Motyka RJ and Streveler G (2012) A complex relationship between calving glaciers and climate. EOS Trans. Amer. Geophys. Union, 92, 305-312 (doi: 10.1029/2011EO370001)

Rignot $\mathrm{E}$ and Kangnaratham P (2006) Changes in the velocity structure of the Greenland Ice Sheet. Science, 311, 986-990 (doi: 10.1126/science.1121381)

Rignot E, Braaten D, Gogineni SP, Krabill WB and McConnell JR (2004) Rapid ice discharge from southeast Greenland glaciers. Geophys. Res. Lett., 31, L10401 (doi: 10.1029/2004GL019474)

Schild KM and Hamilton GS (2013) Seasonal variations of outlet glacier terminus position in Greenland. J. Glaciol., 59(216), 759-770 (doi: 10.3189/2013JoG12J238)

Schjøth F and 5 others (2012) Campaign to map the bathymetry of a major Greenland fjord. EOS Trans. Amer. Geophys. Union, 93 (14), 1 (doi: 10.1029/2012EO140001)

Schmith T and Hansen C (2003) Fram Strait ice export during the 19th and 20th centuries: multiyear ice from southwestern Greenland. J. Clim., 16, 2782-2791 (doi: 10.1175/1520-0442 (2003)016<2782:FSIEDT > 2.0.CO;2)

Seale A, Christoffersen P, Mugford RI and O'Leary M (2011) Ocean forcing of the Greenland Ice Sheet: calving fronts and patterns of retreat identified by automatic satellite monitoring of eastern outlet glaciers. J. Geophys. Res., 116, F03013 (doi: 10.1029/ 2010JF001847)

Stearns LA and Hamilton GS (2007) Rapid volume loss from two East Greenland outlet glaciers quantified using repeat stereo satellite imagery. Geophys. Res. Lett., 34, L05503 (doi: 10.1029/ 2006GL028982)

Straneo F and Heimbach P (2013) North Atlantic warming and the retreat of Greenland's outlet glaciers. Nature, 504, 36-43 (doi: 10.1038 /nature12854)

Straneo F and 6 others (2010) Rapid circulation of warm subtropical waters in a major glacial fjord off East Greenland. Nature Geosci., 3, 182-186 (doi: 10.1038/NGEO764)

van den Broeke $M$ and 8 others (2009) Partitioning recent Greenland mass loss. Science, 326, 984-986 (doi: 10.1126/science. 1178176)

Walsh KM, Howat IM, Ahn Y and Enderlin EM (2012) Changes in the marine-terminating glaciers of central east Greenland, 20002010. Cryosphere, 6, 211-220 (doi: 10.5194/tc-6-211-2012)

Whillans I and Tseng Y (1995) Automatic tracking of crevasses on satellite images. Cold Regions Sci. Technol., 23, 201-214 (doi: 10.1016/0165-232X(94)00009-M) 